\title{
'REALITY IS For THOSE WHO CANNOT SUSTAIN THE DREAM': FANTASIES OF SELFHOOD IN LEGAL TEXTS
}

\author{
RAFAE MAŃKO*
}

\section{Introduction: (THE Difficulty OF) Putting ON JoHN NADA'S GLASSES}

The institutional world of law ${ }^{1}$ can be perceived either from an internal or external perspective. ${ }^{2}$ The internal perspective is the one adopted by lawyers, who - to use Artur Kozak's expression - are not only legal 'experts', but also legal 'believers', in the sense that they treat legal concepts and notions as if they really existed. ${ }^{3}$ A legal believer, attached to the internal point of view of the institutional world of law, is unable to notice the law's idxeological character. ${ }^{4}$ As Althusser famously put it, if we are in ideology,

DOI: $10.1515 /$ wrlae-2015-0021

* Ph.D. in law (University of Amsterdam); external fellow at the Centre for the Study of European Contract Law (CSECL), University of Amsterdam. All views expressed in this paper are personal views of the author and do not represent the position of any institution.

${ }^{1}$ I use the notion of an 'institutional world' following Peter Berger and Thomas Luckmann, The Social Construction of Reality: A Treatise in the Sociology of Knowledge (first published 1966, Penguin 1991) 65ff.

${ }^{2}$ Cf Herbert L.A. Hart, The Concept of Law ( $2^{\text {nd }}$ edn, Clarendon Press 1994) 89; Artur Kozak, Myślenie analityczne $w$ nauce prawa i praktyce prawniczej [Analytical Thinking in Legal Scholarship and Legal Practice] (Wydawnictwo Uniwersytetu Wrocławskiego 2010) 80.

${ }^{3}$ Kozak, Myślenie (n 2).

${ }^{4}$ Cf Adam Sulikowski, 'Postmodernistyczne tropy w juryscentryzmie' [Postmodern Tropes in Juriscentrism], in Paweł Jabłoński, Przemysław Kaczmarek, Michał Paździora and Maciej Pichlak (eds), Perspektywy juryscentryzmu [The Perspectives of Juriscentrism] (Prawnicza i $\begin{array}{llll}\text { Ekonomiczna } & \text { Biblioteka } & \text { Cyfrowa } & \text { 2011) }\end{array}$ $<$ http://www.bibliotekacyfrowa.pl/Content/38056/0008.pdf $>$ accessed 8.1.2015. 
we do not notice it: ideology is invisible for us, ${ }^{5}$ it is part of the ordinary nature of things, common sense ${ }^{6}$ or doxa. ${ }^{7}$

In his recent film Pervert's Guide to Ideology ${ }^{8}$, Žižek discusses John Carpenter's science fiction film They Live (1988). In the latter, a jobless vagabond named John Nada finds a hidden box in a church; the box contains dozens of sunglasses. He puts on a pair and discovers that he sees the world differently. First of all, instead of being colourful, everything is black and white. Secondly, when Nada looks at advertisements in newspapers, he sees their hidden ideological content: orders to obey and conform to the system. Thirdly, when he looks at people from the upper classes, as well those who serve to maintain their power (e.g. policemen), he sees that, in fact, they are not human beings, but humanoid aliens with strange faces. In analysing They Live, Žižek focuses on a key scene where Nadia tries to persuade his friend, Frank, to put on a pair of these special 'ideological' sunglasses and find out the hidden truth about the world. Frank violently opposes her, and the two fight. In the end, Nadia wins the confrontation and forces Frank to put the glasses on, who therefore goes on to see the truth about the world.

Confronting the law as a form of ideology can be compared to putting on a pair of special glasses from They Live. It is not an easy task, especially for lawyers who are very strongly attached to the internal point of view as part of their professional habitus, ${ }^{9}$ and I would not be surprised if Frank's reaction of violent opposition towards the unmasking of the ideological lie were the rule rather than the exception. Nevertheless, with this essay I hope to contribute to an ideological demistification of law.

I will put forward a methodology for subjecting legal texts to a critique of ideology, understood as the identification of its symptoms, that is points of breakdown of the ideological field which are simultaneously necessary for the field to achieve its closure. ${ }^{10}$ The paradox of symptoms is that they are inevitable for the ideological field, yet they undermine it, opening up a space for its crtitique. The aim of this paper is therefore to confront the fundamental fantasies conveyed by legal ideology. I will approach ideological fantasies in strict connection with ideological

\footnotetext{
5 Louis Althusser, 'Ideology and Ideological State Apparatus (Notes Towards and Investigation)' in idem, Lenin and Philosophy and Other Essays (Ben Brewster tr, Aakar 2006) 118.

${ }^{6}$ Hugh Collins, Marxism and Law (first published 1982, OUP 1988) 67.

${ }^{7}$ Doxa, a notion taken from Bourdieu's critical sociology, denotes 'a set of hidden assumptions (comprising cognitive schemata and schemata of action) which are not put into doubt. [...] Individuals who participate in a given field [or "institutional world" in Berger's and Luckmann's terminology - R.M.] accept them in non-reflexively, as a sui generis "credo", something obvious which is not doubted upon' (Hanna Dębska, 'W okowach prawniczego sensus communis: O trudnościach uprawiania krytycznie zorientowanej socjologii prawa' [Shackled by the Legal Sensus Communis: On the Difficulties of Critically Oriented Sociology of Law] (2014) 8 Archiwum Filozofii Prawa i Filozofii Społecznej 18, 25).

${ }^{8}$ The Pervert's Guide to Ideology, written by Slavoj Žižek, directed by Sophie Fiennes (136 minutes, Zeitgeist Films, 2012).

9 Cf Dębska, 'W okowach' (n 7); Hanna Dębska 'Iluzje prawniczego Rozumu: O społecznych warunkach praktyk (bez)refleksyjnych' [Illusions of the Legal Mind: On the Social Conditions of (Non-)Reflexive Practices] (2014) 42 Studia Prawno-Ekonomiczne 11. ${ }^{10}$ Slavoj Žižek, The Sublime Object of Ideology (first published 1989, Verso 2008) 16.
} 
interpellation, i.e. the process by which a human individual is transformed into a subject of ideology. Ideological interpellation of individuals into subjects is one of the chief operations of the law, which, in its current form, is based on the fundamental assumption that human beings are subjects of rights and duties.

For the sake of clarity I wish to emphaise that the ideological operation of the law need not be an intentional act undertaken by legislators, judges or legal academics with the aim of deceiving themselves, each other, or society at large. Following Hugh Collins I contend that:

'The dominant ideology represents common sense understanding of the world and elementary principles of morality. ${ }^{, 11}$

Therefore, legislators or judges, when engaged in lawmaking and legal interpretation, conciously think that what they are cloaking in legal form is rather 'common sense' or 'elementary principles of morality' rather than ideological premises. ${ }^{12}$

\section{NOT A DREAM-LIKE ILLUSION: IDEOLOGY AS A TOOL OF CRITIQUe}

\section{Fantasy and the status quo}

Žižek's notion of ideology is undoubtedly an original one, both against the background of Marxist and non-Marxist concepts of ideology. ${ }^{13}$ The chief theoretical innovation put forward by the intellectual 'Giant of Ljubljana' is the emphasis put on the linkage between the notion of 'ideology' and that of 'fantasy'. Following Jacques Lacan's view that in the opposition between dream and reality, fantasy must be placed on the side of reality, ${ }^{14}$ Žižek makes the famous claim that 'reality is for those who cannot support [sustain] the dream ${ }^{15}$. In a classical passage from the Sublime Object of Ideology, Žižek points out that:

"Ideology is not a dreamlike illusion that we build to escape insupportable reality; in its basic dimension it is a fantasyconstruction which serves as a support for our "reality" itself: an "illusion" which structures our effective, real social relations and thereby masks some insupportable, real, impossible kernel (conceptualized by Emesto Laclau and Chantal Mouffe as "antagonism": a traumatic social division which cannot be symbolized). The function of ideology is not to offer us a point of

\footnotetext{
${ }^{11}$ Collins, Marxism and Law (n 6) 67.

12 ibid 73.

${ }^{13}$ Robert Pfaller, 'Interpassivity and Misdemeanors: The Analysis of Ideology and the Žižekian Toolbox' (2007) 1 (1) International Journal of Žižek Studies 1, 36. For an analysis of the differences between the (Marxist) notion of ideology and Bourdieu's notion of doxa see Hanna Dębska, 'Law's Symbolic Power: Beyond the Marxist Conception of Ideology', (2015) 5 (1) Wrocław Review of Law, Administration and Economics 5.

14 Žižek, The Sublime Object (n 10) 44.

15 ibid 45.
} 
escape from our reality but to offer us the social reality itself as an escape from some traumatic, real kernel."16

In the words of Polish philosopher Mariusz Burzyk, the fantasy is a 'defence mechanism of the ego, a scenario according to which the ego organises and interprets reality in its own way which gives it pleasure'. ${ }^{17}$ Burzyk points out that essentially, "for reality to be bearable it [...] is always filtered and deformed by the fantasy mechanism." ${ }^{18}$ Ideology gives the subject "an illusion that $[\ldots]$ he has taken control over himself and is [...] therefore capable of controlling his choices in a fully concious way. ${ }^{19}$ Ideology plays an important role in the political dimension: its serves to protect the status quo, it "masks reality, misrepresents reality, creating a fantasy world to allow the continuation of a system." ${ }^{20}$ Indeed, "[t] he fundamental aim of ideological fantasy is to silence social antagonism." ${ }^{21}$ From an epistemological point of view, we can, following Žižek, compare ideological fantasy to a 'frame' which we superimpose on raw facts of social reality in order to understand and interpret it. $^{22}$

\section{The Symbolic, Imaginary and Real}

Linking the theory of ideology with Lacan's notion of three psychoanalytical registers (the Symbolic, Imaginary and the Real), Žižek points out that ideological interpellation occurs within the Imaginary and Symbolic under the domination of the Symbolic. ${ }^{23}$ It is appropriate to recall here that, according to Lacan, the Imaginary concerns the illusory surface of phenomena which conceals their inner structure, ${ }^{24}$ and is linked to our selfimage. ${ }^{25}$ The Symbolic order, in contrast, is the big Other, that is the expectations of society towards the subject.

The pair of Imaginary vs Symbolic is coupled with the pair of the Ideal Ego vs. the Ego-Ideal - the Ideal Ego (in the Imaginary register) denotes a vision of the self with which the subject identifies, ${ }^{26}$ whils the Ego-Ideal (in the Symbolic register) denotes the point of view from which the subject views himself, ${ }^{27}$ the gaze which the subject wants to impress. ${ }^{28}$ The Ideal Ego vs Ego-Ideal distinction can be illustrated using the example of a soldier: he is

\footnotetext{
16 ibid 45.

17 Mateusz Burzyk, 'Psychoanaliza a polityka: stawka podmiotu' [Psychoanalysis and Politics: the Stake of the Subject] (2013) 35 Diametros 1, 11-12. All translations from Polish are the Author's.

${ }^{18}$ ibid 12 , footnote 48 .

19 ibid 12

${ }^{20}$ David Marrani, 'Althusser in "Avatar"', in Laurent de Sutter (ed), Althusser and Law (Routledge 2013) 105.

${ }^{21}$ George I. García and Carlos Aguilar Sánchez, 'Psychoanalysis and politics: the theory of ideology in Slavoj Žižek’ (2008) 2 (3) International Journal of Žižek Studies 1, 9.

22 Žižek, The Sublime Object (n 10) 138.

23 ibid 123.

${ }^{24}$ Dylan Evans, An Introductory Dictionary of Lacanian Psychoanalysis (Routledge 1996) 82.

${ }^{25}$ Bruce Fink, A Clinical Introduction to Lacanian Psychoanalysis: Theory and Technique (first published 1997, Harvard UP 1999) 24.

${ }^{26}$ ibid 116.

27 ibid.

${ }^{28}$ Burzyk, 'Psychoanaliza a polityka' (n 17) 8.
} 
expected to identify with the army's Commander-in-Chief as his Ego-Ideal (i.e. to identify with the Commander-in-Chief's point of view upon himself, the solider, i.e. be fearless, risk his life for the victory, eat canned shit...), but is not expected to identify with that Commander as his Ideal Ego (i.e. the solider should not want to be like the Commander-in-Chief, i.e. give orders, hide in a safe bunker far away from the front drinking good cognac...). ${ }^{29}$ Both forms of identification, that is the symbolic and imaginary, are tightly interconnected and complementary. This is because imaginary identification (with the Ideal Ego) takes place under the gaze of the big Other (the Symbolic order); the Ideal Ego is always constructed from the point of view of a given Ego-Ideal. ${ }^{30}$ Therefore the Symbolic order (the Ego-Ideal/big Other) dominates over the Imaginary order (the Ideal Ego). ${ }^{31}$

A combination of the symbolic and imaginary identification causes the effect known as retroversion, that is the subject's illusion as to his autonomy, which masks his fundamental dependence upon the big Other who is the subject's actual, but decentred, cause. ${ }^{32}$ The effect of ideology is therefore the subject's symbolic identification with a certain 'signifying feature' in the big Other. ${ }^{33}$

The price paid for this illusion of autonomy is high: the subject's identification not only with the big Other, but also the imaginary other, inevitably leads to his alientation. ${ }^{34}$ This alienation is a consequence of a discrepancy between the 'actual' self and the imaginary self (reflected in the mirror). The metaphor of the 'mirror scene' is based on a situation in which:

"a child commences to recognise his reflection in the mirror $[. .$.$] and$ starts to [...] identify with this reflection. [...] This is the beginning of alienation: the picture seen in the mirror helps to obtain an image of one's own Self, but on the other hand it remains forever something alien, because it is inverted and not necessarily the same size [as the true Self], and above all it is external and distanced." 35 (emphasis added)

What is important in Žižek's notion of ideology is that he stresses the objective, rather than subjective character of ideology, thereby distancing himself from traditional Marxist accounts under which ideology was equated with 'false conciousness' in line with the formula 'they do not know it, but they are doing it ${ }^{\text {, }}$. In its place, relying on Sloderdijk's notion of the 'cynical reason' Žižek proposes the formula 'they know very well what they are doing, but still, they are doing it ${ }^{37}$. Žižek justifies this approach by referring to the fact that in modern societies it is typical to demonstrate a certain distance towards the hegemonic ideology, and that this distance is part of the

\footnotetext{
${ }^{29}$ Henry Krips, 'Interpellation, Populism, and Perversion: Althusser, Laclau and Lacan' (2007) 2 Filozofski Vestnik 81, 88.

30 Žižek, The Sublime Object (n 10) 117.

${ }^{31}$ ibid 123.

32 ibid 116

33 ibid.

34 ibid.

${ }^{35}$ Burzyk, 'Psychoanaliza a polityka' (n 17) 4-5.

${ }^{36}$ Žižek, The Sublime Object (n 10) 24.

37 ibid 30.
} 
ideological game itself. ${ }^{38}$ What is important is that the distance does not, as it might intuitively seem, weaken the hegemonic ideology, but rather strengthens it because it contributes to masking the role played by the ideological fantasy with regard to the structuring of social reality. ${ }^{39}$ The objective character of ideology also follows from the fact that its locus is not in the conciousness of individuals, but in the social practices in which ideology is materialised. $^{40}$

\section{Interpellation: from individual to subject}

The notion of ideological interpellation is the key linkage between the human individual and ideology, or, to use Lacanian parlance, between the subject and the big Other. ${ }^{41}$ The notion of 'interpellation' was introduced by Louis Althusser, who referred to it as the mechanism whereby a biological, pre-ideological human being becomes a subject of ideology. As Adam Sulikowski emphasized, for Althusser the 'notion of a human being as a subject $[. .$.$] is not a neutral epistemic notion' { }^{42}$ To the contrary, as Althusser himself pointed out, this notion is in fact:

"the philosophical form of the bourgeois ideology that has

dominated history for five centuries and that (...) still reigns in large

sections of idealist philosophy and constitutes the implicit

philosophy of psychology, morality and political economy." 43

In French, the term coined by Althusser - 'interpellation' - has interesting connotations, having essentially three meanings: (1) to refer to someone in a violent way demanding something; (2) to ask someone for their identity; (3) to cause an echo in someone. ${ }^{44}$ According to philosopher and psychologist Szymon Wróbel, this ambiguity of the notion of interpellation:

"has survived in the ambiguity of the very contruction of subjectivity, whose character is at the same time subversive, seditious, anarchic, but also subjugating, normative and normalising." 45

Keeping Wróbel's remarks in mind, let me recall Althusser's definition of ideological interpellation which rests on the metaphor of a policeman hailing a subject:

“...ideology 'acts' or 'functions' in such a way that it 'recruits' subjects among individuals (it recruits them all), or 'transforms' individuals into subjects (it transforms them all) by the very precise operation which I have called interpellation or hailing, and which can be

\footnotetext{
38 ibid 24.

39 ibid 30 .

40 ibid $31,33$.

${ }^{41}$ The present section draws on my earlier paper on ideological interpellation - Rafał Mańko, 'Koncepcja interpelacji ideologicznej a krytyczny dyskurs o prawie' [The Notion of Ideological Interpellation and Critical Discourse on Law] (2014) 8 Archiwum Filozofii Prawa i Filozofii Społecznej 41.

${ }^{42}$ Adam Sulikowski, Posthumanizm a prawoznawstwo [Posthumanism and Jurisprudence] (Wydawnictwo Uniwersytetu Opolskiego 2013) 98.

${ }^{43}$ Louis Althusser, 'On Marx and Freud' (1991) 4 (1) Rethinking Marxism: A Journal of Economics, Culture \& Society 17, 23-24.

${ }^{44}$ Translator's note (21) in Louis Althusser, Ideologie $i$ aparaty ideologiczne państwa (Studenckie Koło Filozofii Marksistowskiej UW 2006) 22.

${ }^{45}$ Szymon Wróbel, 'Efekt interpelacji' [The Effect of Interpellation] (2012) 56 Principia 173, 175.
} 
imagined along the lines of the most commonplace everyday police (or other) hailing: "Hey, you there!"

Assuming that the theoretical scene I have imagined takes place in the street, the hailed individual will turn around. By this mere onehundred-and-eighty-degree physical conversion, he becomes a subject. Why? Because he has recognized that the hail was 'really' addressed to him, and that 'it was really him who was hailed' (and not someone else)." 46

Althusser's metaphor compares ideology (i.e. the big Other) to a policeman, and the interpellated individual to a passer-by who, for some reason, considers himself to be adressed by the Policeman's shout of 'Hey, you!' The act of consent towards the interpellation (metaphorically expressed by the fact that the passer-by turns always-already around) expresses the necessity of interpellation: the interpellated individuals could not have not turned around. ${ }^{47}$ As Mladen Dolar pointed out, ideological interpellation is similar to an offer made by a thief in a dark alley who gives a passer-by a false alternative: 'money or life'. ${ }^{48}$ This 'alternative' is obviously false, because we can only chose life (and give up the money). If we chose money, we will have to give up life, and therefore, having lost our subjectivity, we will not be able to enjoy the money (after our death inflicted by the thief). Dolar believes that the interpellated individuals' freedom to chose interpellation or not is exactly the same as the freedom of the person asked by the thief. In line with that, Adam Sulikowski remarks that ideological interpellation can be compared to 'animal training within the framework of accepted social practices which impose upon the individual a role, and in consequence also the status of a subject. ${ }^{49}$ Sulikowski's metaphor, in which the human subject is compared to a tamed beast, and the big Other to an animal trainer, is insightful in that it ironically captures the falsehood of our illusions of freedom and choice with regard to ideological interpellation on the one hand, and the ruthlessness of the process itself on the other hand. One could say that human individuals-in-transformation-into-subjects are being brutally maltreated by ideology, which does not spare the rod.

In that context it comes as no suprise that Althusser's notion of ideology is quite pessimistic. The French phislopher writes that interpellated subjects:

"“"work", they "work by themselves" in the vast majority of cases, with the exception of "bad subjects" who on occasion provoke the intervention of one of the detachments of the (repressive) State apparatus. But the vast majority of (good) subjects work all right "all by themselves", i.e. by ideology (...).",50

The Althusserian subject is therefore a subjugated and subjected one, tamed and trained, automatised and obedient, unable (in the vast majority of cases)

\footnotetext{
${ }^{46}$ Althusser, 'Ideology' (n 5) 118.

${ }^{47}$ Pierre Macherey and Stephanie Bundy, 'Judith Butler and the Althusserian theory of subjection', (2013) 1 (2) Décalages: An Althusser Studies Journal 1, 16.

${ }^{48}$ Mladen Dolar, 'Beyond Interpellation' (1993) 6 (2) Qui Parle 73, 82.

49 Sulikowski, Posthumanizm (n 42) 98.

${ }^{50}$ Althusser, 'Ideology' (n 5) 123.
} 
to oppose the hegemonic ideology. One could ask whether this pessimistic view is indeed that far from reality?

And this is exactly where psychoanalytic theory can step in, offering a way out of the Althusserian deadlock of subjectivation-subjection. According to Slovenian psychoanalyst Mladen Dolar:

"For Althusser, the subject is what makes ideology work; for psychoanalysis, the subject emerges where ideology fails. The illusion of autonomy may well be necessary, but so is its failure; the coverup never holds fast. The entire psychoanalytic apparatus starts from this point." $" 51$

Although 'individuals are always-already subjects' ${ }^{52}$ nevertheless, as Wróbel points out:

"the subject is not only an effect of subjugation (...) but also a subversive power, resistance which creates a possibility for the structure to break in the most unexpected circumstances." 53

The potential for resistance towards interpellation arises from the fact that 'the effect of interpellation is never full, a subject never ends the process of concluding his decision on identity. ${ }^{54}$ In other words, as Dolar points out,

"...there is a part of the individual that cannot successfully pass into the subject, an element of "preideological" and "presubjective" materia prima that comes to haunt subjectivity once it is constituted as such. A part of external materiality remains that cannot be successfully integrated in the interior. Interpellation was based on a happy transition from a pre-ideological state into ideology: success wipes out the traces of its origin and results in belief in the fullyacheived autonomy and self-transparency of the subject. The subject is experienced as a causa sui-in itself an inescapable illusion once the operation is completed. The psychoanalytic point of departure is the remainder produced by the operation; psychoanalysis does not deny the cut, it only adds a remainder. The clean cut is always unclean; it cannot produce the flawless interiority of an autonomous subject.",55

Turning now to Žižek's notion of ideological interpellation, I have to point out that he prefers the Lacanian term of 'quilting' (capitonnage) to the Althusserian 'interpellation', although he makes it clear that the same phenomenon is at stake, despite the differing terminology.

\footnotetext{
${ }^{51}$ Dolar, 'Beyond' (n 48) 78.

${ }^{52}$ Althusser, 'Ideology' (n 5) 119.

${ }^{53}$ Wróbel, 'Efekt' (n 45) 179-180.

54 ibid 182 .

${ }^{55}$ Dolar, 'Beyond' (n 48) 77.
}

56 Žižek, The Sublime Object (n 10) 112. Using conceptual metaphor theory, one could say that Althusser and Žižek rely on different source domains to explain the same target domain. Whereas Althusser's metaphor relies on the 'policeman scene' (IDEOLOGICAL INTERPELLATION IS LIKE A POLICEMAN HAILING A PERSON IN THE STREET), Žižek relies on the 'quilting point' (IDEOLOGICAL INTERPELLATION IS LIKE QUILTING A BUTTON TO A FRAME). As will be seen further, actually the 'quilting point' metaphor is not the only one, especially if we examine such expressions as "chain" or "floating", used by Žižek. In analysing conceptual metaphors I rely mainly on George Lakoff and Mark Johnson, Metaphors We Live By (first published 1980, University of Chicago Press 2003); Zoltán Kövecses, Metaphor: A Practical Introduction (2nd ed, OUP 2010) and Stefan Larsson, Metaphors and Norms: Understanding Copyright Law in a Digital Society (Lund University Press 2012). Cf Alberto Vespaziani, 
Quilting/interpellation occurs, in Žižekian terms, in the moment when the big Other addresses the individual with the call of a certain Master-Signifier:

"The point de capiton is the point through which the subject is "sewn" to the signifier, and at the same time the point which interpellates individual into subject by addressing it with the call of a certain master-signifier ("Communism", "God", "Freedom", "America") - in a word, it is the point of the subjectivation of the signifier's chain." 57 The above passage clearly indicates the importance of the notion of a MasterSignifier for Žižek's conception of ideological interpellation. He gives examples of four Master-Signifiers here, that is 'Communism', 'God, 'Freedom' and 'America', obviously each of them representing different ideologies. 'Communism' stands for the Marxist ideology, 'God' for any kind of religious ideology, such as e.g. Christianity, 'Freedom' stands for liberal and neoliberal ideologies and 'America' (in the sense of United States) stands for the patriotic ideology of the USA. But what is the exact function of the Master-Signifier, what is its modus operandi with regard to the process of interpellation? Žižek clarifies this aspect in a later passage:

"Signifiers which are still in a "floating" state - whose signification is not yet fixed - follow one another. Then, at a certain point - precisely the point at which the intention pierces the signifier's chain, traverses it - some signifier fixes retroactively the meaning of the chain, sews the meaning to the signifier, halts the sliding of the meaning."

Žižek draws on the conceptual opposition between a 'signifier' and a 'signified', where a 'signifier' is a bearer of meaning (e.g. a term, concept, symbol etc.), whereas a 'signified' is the meaning denoted by that signifier. Žižek distinguished between two phases: in the first phase, signifiers are 'in a "floating" state', that is their 'signification is not yet fixed'. This means that they do not have a determined signified at this stage. In the second phase, signifiers already have a meaning 'sown to them', through a retroactive operation of the Master-Signifier. Žižek explains the concrete implications of this model for ideology:

"To grasp this fully, we have only to remember the above-mentioned example of ideological "quilting": in the ideological space float signifiers like "freedom", "state", "justice", "peace".... and then their chain is supplemented with some master-signifier ("Communism") which retroactively determines their (Communist) meaning: "freedom" is effective only through surmounting bourgeois formal freedom, which is merely a form of slavery; the "state" is the means by which the ruling class guarantees the conditions of its rule; market exchange cannot be "just and equitable" because the very form of equivalent exchange between labour and capital implies exploitation; "war" is inherent to class society as such; only the socialist revolution

\footnotetext{
'Towards a Hermeneutical Approach to Legal Metaphor', in Thomas Bustamante and Oche Onazi (eds) Human Rights, Language and Law (Franz Steiner/Nomos 2012). The use of small capitals to denote conceptual metaphors follows the convention used by Lakoff and Johnson.

57 Žižek, The Sublime Object (n 10) 112.

58 ibid 113.
} 
can bring about lasting "peace", and so forth. (Liberal-democratic "quilting" would, of course, produce a quite different articulation of meaning; conservative "quilting" a meaning opposed to both previous fields, and so on.)"

What Žižek essentially argues is that signifiers such as 'freedom, 'state', 'justice', 'peace' and so forth do not point to any specific signified (they 'float'), until and unless a certain MasterSignifier, such as 'Communism', 'Freedom' or 'God', determines retroactively their meaning and thereby ties them to a specific signified. To put it in other words, there is no 'freedom', 'justice' or 'peace' in the abstract; to the contrary, there is only either communist, Christian or liberal 'freedom', 'justice' etc. These concepts are in a way empty outside any given ideology; only within a specific ideology do they mean something and make sense.

Lawyers are very familiar with this phenomenon with regard to general clauses: what is Treu und Glauben in the German Civil Code ${ }^{60}$ depends heavily on the current Master-Signifier, and the radical transformation of the meaning of this general clause under the Nazi regime (when it became loaded with anti-Semitic content), and then, once again, under the liberal-democratic Federal Republic of Germany, is a case in point. Using Žižekian terminology, one could say that the signifier of 'Treu und Glauben' floated freely, and was first quilted under the Weimar Republic, then in Nazi Germany, ${ }^{61}$ and then, once again, in the lib-dem Western Germany, ${ }^{62}$ each time by a different Master-Signifier, and each time tied to a different signified. We expierence the same phenomenon with regard to the signifier of 'freedom', which under the neoliberal Master-Signifier means freedom of entrepreneurial individuals from state, ${ }^{63}$ rather than actual freedom which is possible only with a certain minimum income.

\section{4. 'A past which has never existed': the Real}

A psychoanalytical account of ideological interpellation would be incomplete without the notion of the Real. Indeed, a feature of this account is the stress placed upon a certain lack which characterises both parties to the interpellative relationship, that is the interpellated subject and the interpellating Subject, the big Other. ${ }^{64}$ The lack on the side of the interpellated subject is the Real, the element of the individual which precedes interpellation but actually has never been, to use Dollar's expression: 'a past which has never existed ${ }^{\prime 65}$. In clinical terms, the Real is defined as

\footnotetext{
59 ibid.

60 'Treu und Glauben', literally 'trust and faith', is usually translated into English as 'good faith' (bona fides). It is a general clause found in $\S 242$ of the German Civil Code (BGB) of 1896 which has given rise to extensive judicial law-making. The judge-made equitable law based on $\S 242$ BGB is referred to as the 'inner system' of the general clause.

${ }^{61}$ On which see, specifically, Bernd Rüthers, Die unbegrentzte Auslegung: Zum Wandel der Privatrechtsordnung im Nationalsozialismus (7th ed, Mohr Siebeck 2012) 224-236.

${ }^{62}$ See e.g. Reinhard Zimmermann, The New German Law of Obligations: Historical and Comparative Perspectives (OUP 2005) 25-28.

${ }^{63}$ Janusz Reykowski, 'Wolność gospodarcza jako ideologia' [Economic Freedom as Ideology] (2013) 210 Studia Socjologiczne 7, 9.

${ }^{64}$ Dolar, 'Beyond' (n 48) 88; Mańko, 'Koncepcja' (n 41) 47.

${ }^{65}$ Dolar, 'Beyond' (n 48) 88.
} 
"that which has not yet been symbolized, not yet put into words; it is what, at a certain moment, is unspeakable (the "impossible to say") for the analysand but not necessarily for the analyst." 66

The analyst's efforts at interpretation aim at 'hitting the real'. As Fink indicates:

"Insofar as interpretation hits the real, it does not so much hit the truth as create it. For truth exists only within language (it is a property of statements), and thus there is no truth of that which cannot yet be said. Truth is not so much "found" or "uncovered" by interpretation, as created by it." $" 67$

For the theorists of psychoanalysis, the Real is equivalent to what did not pass from the preideological individual into the ideological subject, a subject resisting symbolisation which, on that account, can be used - as a symptom - to undermine the efficacy of interpellation. ${ }^{68}$ As Sheridan elucidates:

"The "real" [...] stands for what is neither symbolic nor imaginary, and remains foreclosed from the analytic experience, which is an experience of speech. What is prior to the assumption of the symbolic, the real in its "raw" state (in the case of the subject, for instance, the organism and its biological needs), may only be supposed, it is an algebraic $x$. This Lacanian concept of the "real" is not to be confused with reality, which is perfectly knowable: the subject of desire knows no more than that, since for it reality is entirely phantasmatic." 69

It is perhaps the last part of Sheridan's definition of the Real which is particularly worth focusing on: the conception that for the subject 'reality is entirely phantasmatic'. This begs the question of the status of reality in comparison to the Real. According to the words of Žižek quoted above, the ideological fantasy is 'a support for our "reality" itself", it is 'an "illusion" which structures our (...) real social relations "70 The fantasy is not 'a point of escape from our reality'; to the contrary, it 'offer[s] us the social reality itself'. ${ }^{71}$ What does the subject wish to escape from? It is precisely the Real that he wishes to avoid: the ideological fantasy is 'an escape from some traumatic, real kernel', that is 'a traumatic social division which cannot be symbolized'. ${ }^{2}$

\section{LEGAL IDEOLOGY BETWEEN SYMPTOM AND FETISH}

Applying Žižek’s conceptual framework to legal ideology, we can say that legal texts - codes, statutes, judgments, academic writings - are expressions of the Symbolic order, that is the big Other. They convey a certain

\footnotetext{
${ }^{66}$ Fink, An Introduction (n 25) 158.

67 ibid.

${ }^{68}$ Mańko, 'Koncepcja' (n 41) 47.

${ }^{69}$ Alan Sheridan, 'Translators note' in Jacques Lacan, The Four Fundamental Concepts of Psychoanalysis (tr Alan Sheridan, first published 1973, Hogarth Press 1978) 280.

70 Žižek, The Sublime Object (n 10) 45.

71 ibid.

72 ibid.
} 
vision of society - an ideological fantasy - which creates and sustains the social reality. Popular sovereignty, equality before the law, autonomy of the will or responsibility based on guilt - all these concepts represent certain ideological fantasies (in the psychoanalytic meaning of the term). They are fictions: of course, the entire citizenry cannot be a collective 'sovereign', of course people are not really equal before the law (the well-off are usually 'more equal'), of course subjects of private law are not really free and autonomous, of course the notion of 'guilt' in criminal law is a legal construct which departs from psychological findings, ${ }^{73}$ and so forth. And yet, despite the fact that we all know that these fundamental concepts of the legal field are fictitious, we still insist on sticking to them. The list could be multiplied, including the fantasy that judges 'apply' the law and do not 'make it' (popular e.g. in French legal culture), the fantasy that all people 'know' the law, although with its complexity this is utterly impossible, or the fiction that behind legislative texts there stands a 'rational legislator' (a fiction typical for Polish legal culture), although lawyers know very well that legislation tends to be irrational and inconsistent, and so forth.

The fantasies of legal ideology are not points of 'escape from our reality', but 'offer us the social reality itself'. Indeed, the social practice of lawyers (and legal subjects) usually proceeds as if the fantasies of legal ideology were true. Thereby, these fantasies - built into social practices structure those practices, and contribute to the social construction of reality, at least with regard to legal reality (reality of the legal sub-world).

Assuming that legal ideology - the Symbolic order - represents a set of fantasies, we must take the second step and enquire what do these fantasies mask? In other words, a critique of legal ideology must aim at unmasking the Real, the 'impossible kernel', which is masked by the fantasy. This would constitute the first step in the critique of legal ideology. A second step in that critique would be a search for symptoms within the legal ideology itself, that is an analysis of the ideology aimed at revealing its internal inconsistencies.

We must, however, bear in mind the fact, as Žižek has repeatedly stipulated, "in our allegedly "post-ideological" era, ideology functions more and more in a fetishistic mode as opposed to its traditional symptomal mode. ${ }^{, 74}$ Žižek explains that in the symptomal mode:

"... the ideological lie which structures our perception of reality is threatened by symptoms qua "returns of the repressed" - cracks in the fabric of the ideological lie". ${ }^{75}$

This is because in the symptomal mode, which Žižek labels as 'traditional', and which is typical for the modernist, 'ideological era', people still took ideologies seriously, and the exposure of symptoms, that is 'cracks' of the ideology, "exception[s] which distur[b] the surface of the false appearance" ${ }^{, 76}$ would undermine the efficacy of ideology. This is because 'for both Marx and Freud' - representatives of the modern(ist) way of thinking, let us add -

\footnotetext{
${ }^{73}$ A characteristic example is the notion of 'eventual intent' in Polish penal law, under which the perpetrator did not want to commit the crime, but did take into account that the criminal act would nevertheless occur.

${ }^{74}$ Slavoj Žižek, First as Tragedy Then as Farce (Verso 2009) 65.

75 ibid.

76 ibid.
} 
'the way to the truth of a system (of society, of the psyche) leads through what necessarily appears as a "pathological" marginal and accidental distortion of this system: slips of tongue, dreams, symptoms, economic crises. ${ }^{, 77}$

Whilst this may still be true with regard to certain ideologies and certain (naïve) believers, the main mode of functioning of ideology today is the fetishistic mode. This is strictly connected to the cynical approach to ideology, whereby subjects always-already recognise their own ideological 'false conciousness', but nevertheless keep on following the social practices dictated by that ideology. This is because the fetish is actually 'the embodiment of the Lie which enables us to sustain the unbearable truth'. ${ }^{78}$ Žižek explains this mode of ideological functioning by invoking the example of the death of someone beloved:

"in the case of a symptom, I "repress" this death, I try not to think about it, but the repressed trauma returns in the symptom; in the case of a fetish, on the contrary, I "rationally" fully accept the death, and yet I cling to the fetish, to some feature that embodies for me the disavowal of the death. In this sense, a fetish can play the very constructive role of allowing us to cope with a harsh reality: fetishists are not dreamers lost in their own private worlds, they are thoroughgoing "realists" able to accept the way things are because by clinging to their fetish they are able to mitigate the full impact of reality." 79

I contend that the fantasies of legal ideology play a fetishistic, not symptomal role. People cling to those fantasies qua fetishes not out of naïvety or 'false conciousness', and not necessarily even out of cynicism (although this may be the case), but rather because these fantasies or legal myths not only structure legal reality, but also make it bearable. For instance, hard legal positivists who insist on the fact that judges 'apply' legal texts and do not 'make' the law may be naïve or cynical, but more probably they are simply realists. By insisting on the fantasy of subsumption, they are able to 'mitigate the full impact' of judicial law-making. They rationally accept the fact that judges make the law, but still insist that this is not the case, precisely because in this manner they are able to sustain the unbearable truth, the horror of the legal Real, the 'government of men' (as opposed to the ideological lie of 'government of laws').

Crits, by insisting on the Real of the law - that law ' is politics ${ }^{, 80}$ - did not discover anything new. Under a modernist, symptomal mode of functioning of ideology their 'discovery' would undermine the system. But this did not happen (and the American CLS movement withered away) simply because under the fetishistic mode of ideological life exposing the fact that judges are human beings, and their decisions are dictated by political conviction or personal whim does not change anything. This is neither because lawyers are naïve and really believe that judges are not human

\footnotetext{
77 ibid 101.

78 ibid 65.

79 ibid.

${ }^{80}$ Cf Jaime Llambías-Wolff, 'Law As The Expression Of Politics And The Result Of Its Own Dynamics’ (2014) 3 (5) International Journal of Social Sciences 79, 83-84.
} 
beings, nor because lawyers are cynical ${ }^{81}$ and try to create a false appearance for the gaze of society. Rather, it is because lawyers, and the majority of society together with them, insist on the fetish of 'government of laws, not men' because this fantasy-fetish makes the unbearable humanity of judges somewhat more bearable.

Does this mean that the critique of (legal) ideology has lost any significance? If lawyers not only are not naïve, and perhaps even not cynical, but rather are realist fetishists, what could the purpose of such a critique be? The answer is to be found in the very nature of the fetishist's attachment to his fetish and its function. As Žižek writes,

"fetishists are not dreamers [...] [but] thoroughgoing "realists" able to accept the way things are because by clinging to their fetish they are able to mitigate the full impact of reality."

This means in practice that the function of the fantasy qua fetish is to allow the subjects of ideology to escape their dream and to accept the status quo. The function of a critique of legal ideology is precisely to undermine the ideological naturalisation and to forge the conditions of possibility for considering alternative arrangements.

\section{Fantasies OF SElF IN LEgal TeXtS}

\section{General remarks}

The place occupied by legal texts and practices in the ideological superstructure is undoubtedly special. ${ }^{82}$ Already Althusser pointed out that 'above all with the rise of legal ideology, the category of the subject (...) is the constitutive category of all ideology'. ${ }^{83}$ And, as Belgian philosopher of law Laurent de Sutter observed, 'the concept of person' refers to an 'abstract receptacle of the liberties recognised in him as a subject' ${ }^{84}$ Unlike bourgeois legal thinkers, who have been always haunted by 'the fantasy of getting rid of law, ${ }^{85}$ Althusser thought in the opposite direction: how to separate law from the state and politics, thereby enabling a contribution of law to emancipatory politics. ${ }^{86} \mathrm{He}$ saw the key to this operation in getting rid of the

\footnotetext{
${ }^{81}$ As Žižek points out, 'cynics are les non-dupes who errent; what they fail to recognize is the symbolic efficacy of illusions, the way they regulate activity which generates social reality' (Žižek, First as Tragedy (n 74) 78).

${ }^{82}$ Cf Mańko, 'Koncepcja' (n 41) 41-42.

${ }^{83}$ Althusser, Ideology (n 25) 115-116, empasis added.

84 ibid.

${ }^{85}$ Laurent De Sutter, 'Introduction' in De Sutter (ed), Althusser and Law (n 20) 5.

${ }^{86}$ ibid 8. Curiously enough, the dream of 'withering away of the law' was not foreign to Lenin, who put forward the view that in higher phase of communist society law would 'wither away' (die out) and be replaced by 'principles of social life'. See Vladimir Iliich Lenin, The State and Revolution (first published 1918, Penguin 2009). Even more curiously, this expression ('principles of social life') was later used both in Soviet and Polish law under Real Socialism, but had scarcely to do with Lenin's original conception. For more details see Rafał Mańko, 'Quality of Legislation Following a Transition from Really Existing Socialism to Capitalism: A Case Study of General Clauses in Polish Private Law' in Jānis Rozenfelds (ed) The Quality of Legal Acts and its Importance in Contemporary Legal Space (University of Latvia Press 2012).
} 
subject and conceiving of law without this ideological notion. As De Sutter puts it:

"To get rid of the legal subject is (...) the first hit of a domino game: by separating law from the legal subject, law is also separated from the State; and by separating law from the State, it is also separated from bourgeois legal ideology. Such is the challenge presented by Althusser: to succeed in conceiving a law without subject or State -a purely operational law." 87

But it was not only Althusser who noted the curious emphasis placed by legal texts on subjects and their subjective rights. Even Hans Kelsen, very far from any Marxist inspirations and certainly not a critical legal scholar, noted that:

"Just as traditional theory places "right" ahead of "obligation", so it regards the legal subject primarily as a subject of rights and only secondarily as a subject of legal obligations. [...] Just as in the concept of subjektives Recht [subjective right] so in the concept of Rechtssubjekt [legal subject] the idea predominates [...] of the existence of a legal subject which is to be found [...] in the individual and in certain corporate bodies [...]." 88

Kelsen is actually critical of the notion of subject and does not conceal its ideological function. He writes:

"The ideological function of the self-contradictory conception of the legal subject as the holder of rights is [...] to maintain the idea that the existence of the legal subjct as the holder of a right - and this means holder of a property right - is in a category that transcends the objective law, namely the positive law [...] changeable by man; in other words, to maintain the idea that property is an institution protected by a barrier insurmountable by the legal order. ${ }^{, 89}$.

To put it in other words, Kelsen unmasked the ideological function of the notion of subject. The fantasy of a subject pre-existing the positive legal order is simply to strengthen the class power of the 'haves' vis-a-vis the 'have-nots'. Thanks to the ideological fiction, private property becomes 'protected by a barrier insurmontable by the legal order', writes Kelsen. The fantasy of the eternal subject masks the kernel of a fundamental social antagonism.

If we agree with Althusser and Kelsen that subjectivity per se is already an ideological fiction, a fantasy masking the social Real, one could go a step further and enquire about the fantasies connected to specific forms of legal subjectivity, such as 'citizen', 'consumer', 'employee' or 'trader'. However, before going into any further detail of such ideological subjectivities offered by law, let me first outline (in the subsequent section) the methodological aspects of such a critique of legal texts.

\section{Methodological aspects}

The methodology of criticising fantasies of self put forward in legal texts must depart from the assumption that such fantasies are inherently linked with the ideological interpellation of individuals into legal subjects.

\footnotetext{
${ }^{87}$ De Sutter, 'Introduction' (n 85) 8.

${ }^{88}$ Hans Kelsen, Pure Theory of Law (tr Max Night, Lawbook Exchange 2005) 169-170.

${ }^{89}$ ibid 171.
} 
Just like ideology in general, legal ideology cannot exist without the subject; actually, as any ideology, legal ideology exists for subjects and through subjects (Althusser).$^{90}$ If the focus of critique of legal ideology is to be placed on interpellation, it is necessary to develop a methodological approach (a 'protocol' of critique) which will allow us to approach legal texts with a view to identifying and subjecting to critique those fragments which directly address individuals as always-already legal subjects. ${ }^{91}$

In the following sub-sections I identify seven possible stages of the ideological critique of legal texts with view to identifiyng the places of interpellation (4.2.1), analysing the signifier of interpellation (4.2.2), the subject of 'counter-interpellation' (4.2.3), identyfying subjectivities disavowed in the act of interpellation (4.2.4), analysing the Ideal Ego proposed in the interpellation (4.2.5) and finally confronting the fantasy conveyed by the interpellation with the Real that it seeks to mask (4.2.6).

\section{a. Places of interpellation}

The object of critique of legal ideology is primarily a legal text: a piece of legislation, a judgment, a pleading or a scholarly article or book. The material, composed mainly of words (illustrations rarely appear in legal texts) dictates the first step of the critical operation, namely the search for 'places of interpellation', those fragments of the text where the fantasy of selfhood is particularly dense. As a rule of thumb, such 'places of interpellation' can be identified with words or phrases in which the legal text addresses individuals directly as subjects, using signifiers prima facie referring to a certain form of subjectivity, such as 'citizen', 'foreigner', 'natural person', 'slave', 'peasant', 'worker', 'employee', 'consumer', 'accused' and so forth.

Obviously, the identification of such places of interpellation is nothing but a starting point for the critique of the text, and once the forms of legal subjectivity in question are identified, the operation of critique must go further in order to reconstruct the entire vision of subjectivity proposed by the legal text qua ideological text.

\section{b. Signifier of interpllation}

Once the 'hinging points' of the ideological fantasy with the human individual, namely the 'places of interpellation', are identified (4.2.1 above), the next step is to analyse the signifier under which the big Other (the imaginary 'Legislator', the court...) addresses the individual qua subject. Obviously, this is only a preliminary and undoubtedly superficial step; nevertheless it can already provide an insight into the ideological fantasy conveyed by the act of legal interpellation.

In particular, the notions of 'radial categories', and 'prototype effects', proposed (in the legal context) by legal cognitivist Steven L. Winter,

\footnotetext{
${ }^{90}$ Which does not rule out Althusser's dream of a law without a subject; a law which would not be ideological, at least in this dimension. Nevertheless actually existing law, as it is known to us today, is raised on the foundation of the subject, as rightly underlined by Kelsen. ${ }^{91}$ The 'protocol' of critique presented and applied here draws on my earlier paper: Mańko, 'Koncepcja' (n 41) 48-53.
} 
can be of assistance here. ${ }^{92}$ Considering that human thought is concrete (even if it deals with abstract concepts), ${ }^{93}$ Winter contends that the signifiers used in legal discourse arouse in readers determined, empirically verifiable associations with concrete signified. ${ }^{94}$ This is a result of the so-called 'prototype effect', ${ }^{95}$ that is the fact that certain 'prototypes' (typical signified) constitute cognitive reference points, ${ }^{96}$ as opposed to peripheral signified, which are linked to the signifier qua modifications (extensions) of the central, prototypical case. ${ }^{97}$ Winter illustrates this concept by referring to the signifier 'mother' and its prototypical reference point which, as he notes, has shifted over time (from married, full-time home-employed mother to not necessarily married, working mother), reflecting social changes (in Western societies). Winter's theory undoubtedly places a great emphasis on the link between human perception of texts and the nature of human thinking (the cognitive aspect), as well as between human thinking about texts and the social context in which that occurs (the contextual aspect). Indeed, the theory of ideological interpellation can benefit greatly from taking those two aspects on board when analysing concrete examples of fantasies of selfhood conveyed by legal texts.

\section{c. The subject of 'counter-interpellation'}

I propose to supplement the notion of interpellation of an individual$q u a$-subject with the notion of 'counter-interpellation', understood as inseparable from the act of interpellation itself, but focused not so much on the subject (of interpellation) as on the subject of the interpellated subject's enemy. The notion of counter-interpellation put forward here draws on Carl Schmitt's concept of the political (das Politische) understood as the distinction between 'friend' and 'enemy', which:

"...denotes the utmost degree of intensity of a union or separation, of an association or dissociation. [...] The political enemy need not be morally evil or aesthetically ugly; he need not appear as an economic competitor, and it may even be advantageous to engage with him in business transactions. But he is, nevertheless, the other, the stranger; and it is sufficient for his nature that he is, in a specially intense way, existentially something different and alien, so that in the extreme case conflicts with him are possible." 98

\footnotetext{
${ }^{92}$ Steven L. Winter, A Clearing in the Forest: Law, Life and Mind (University of Chicago Press 2001) $71 \mathrm{ff}$.

93 ibid 94.

94 ibid 76.

${ }^{95}$ The same is explained by other scientific models. My aim here is not to support in any special way the prototype effect model, but rather to draw attention to the phenomenonon as such.

${ }^{96}$ Winter, A Clearing (n 92) 77-78.

97 ibid 92.

${ }^{98}$ Carl Schmitt, The Concept of the Political, transl. Georg Schwab (University of Chicago Press 2007) 26-27. Cf Mariano Croce and Andrea Salvatore, The Legal Theory of Carl Schmitt (Routlege 2013) 20-21. See also Michał Paździora and Michał Stambulski, 'Co może dać nauce prawa polityczność? Przyczynek do przyszłych badań' [What Can Legal Scholarship Gain from the Notion of the Political? Notes Towards Further Investigations] (2014) 8 Archiwum Filozofii Prawa i Filozofii Społecznej 55.
} 
Whilst Laclau pointed to the element of counter-interpellation (not using the term put forward here) in the case of interpellation by populist ideologies, ${ }^{99}$ and argued that a people can only be constituted by a gesture of exclusion, ${ }^{100}$ I contend that counter-interpellation is not an anomaly, but rather the standard case of any ideological interpellation, not only populist or nationalistic.

In the proposed scheme, the big Other would not only address the subject by a call for identifying with an Ideal Ego (under the gaze of the EgoIdeal), but also would urge the subject to identify with the Ego-Ideal's vision of subjects in some way excluded from the ideological community, condemned by the big Other. I therefore suggest that ideological interpellation occurs within a binary code of the classical opposition of sacrum vs. profranum, shaped in line with the needs of the existing status quo. ${ }^{101}$ Interpellation (any interpellation) is therefore inherently political, and the excluded ones (the counter-interpellated subjects) are the social symptom. ${ }^{102}$

Pointing to the subject of counter-interpellation is, perhaps, not that easy on the textual level (as identifying the subject of 'positive' interpellation), but an insight into the general scheme and economy of the interpellating text will soon reveal the identity of interpellation's 'antisubject'.

I contend that interpellation per legal texts follows the same scheme, and therefore it is possible to compliment the identification of the 'positive' subject of interpellation (favoured in the eyes of the big Other) with the 'negative' subject. Thus, for instance, the citizen (as interpellated e.g. by the Constitution) is opposed to the foreigner; the citizen participates in the sacrum (electoral ritual etc.), from which the profane non-citizen is excluded. 'Consumer' (the subject interpellated by consumer law) is opposed to the 'rogue trader' (his 'enemy' or antagonist). In penal law victims (sacrum) are opposed to criminals (profanum). In contract law, creditors are opposed to debtors, and in property law owners to third parties, and so forth.

The importance of coupling the subject of interpellation with the subject of counter-interpellation stems from the fact that it is impossible to fully perceive the fantasy of selfhood conveyed by ideological interpellation without integrating the anti-subject into the operation of critique. But there is more to the notion of counter-interpellation than only that: it goes right into the ontological dimension of subjectivity, to the extent that it is impossible to 'be human' without excluding certain others (non-subjects) from 'humanity', threreby drawing a line between human and non-human. The subject of counter-interpellation is therefore the symptom of interpellation in the strictest possible sense: the anti-subject is necessary for completion of the act of interpellation (no subject without anti-subject), but at the same time it undermines the interpellation and creates a space for questioning it.

\footnotetext{
99 See Krips, 'Interpellation' (n 29) 93-94.

100 ibid 96.

101 Hanna Dębska, Wtadza - symbol - prawo. Społeczne tworzenie Trybunatu Konstytucyjnego [Power - Symbol - Law: The Social Construction of the Constitutional Court] (Wydawnictwo Sejmowe 2014) 139-140, $242 \mathrm{ff}$.

${ }^{102}$ Krips, 'Interpellation' (n 29) 97.
} 


\section{d. Disavowed subjectivities}

Whereas the subject of counter-interpellation may well be a symptom, he is nevertheless explicitly mentioned in the legal texts. Constitutions set out the rights of citizens, but also regulate the status of foreigners. ${ }^{103}$ The Code of Canon Law provides for the status of Catholics ('Christi fideles') ${ }^{104}$ but also provides for heretics and schismatics. ${ }^{105}$ But this is not the case with all forms of subjectivity. I contend that there are also subjectivities which are actually disavowed by the ideological text. The method for discovering them is the application of the Althusserian 'symptomatic' reading of texts. ${ }^{106}$ Thus, for instance, whilst the Labour Code interpellates individuals as 'employer' and 'employees', it fails to account for the fact that a growing number of de jure self-employed persons remain outside the framework of labour law, working on the basis of civil-law contracts (but remaining de facto subordinated workers). ${ }^{107}$

\section{e. The ideal Ego of interpellation}

An important aspect of ideological interpellation is the ideal Ego indicated to the subject by the big Other (the Ego-Ideal). Interpellation conveys a certain 'symbolic mandate', adressed to the interpellated subject. In the case of strictly legal texts, the reconstruction of the ideal Ego may, in certain cases, require transcending the text itself and looking into its closer or more distant context. Sometimes, however, the features of the interpellated subject are already indicated in the text itself, especially if it is a doctrinal or judicial, rather than purely legislative text. In the case of legislative texts, preambles (if available), motives (of proposals), records of parliamentary debates, as well as features of the rights and duties of legal subjects may serve as indicators allowing to reconstruct the legal subject's ideal Ego (as foreseen by the Symbolic order).

For instance, in the case of a 'consumer', one should keep in mind the fact that interpellation of individuals qua consumers is a relative novelty in legal ideology, and that initially it had met with controversies among lawyers. ${ }^{108}$ Within contract law, the interpellation of certain individuals qua consumers replaced their interpellation to a more abstract subjectivity, namely that of 'contractual parties'. ${ }^{109}$ Interpellation as consumers is

\footnotetext{
${ }^{103}$ See e.g. Article 1 of the Polish Constitution (1997): 'The Republic of Poland shall be the common good of all its citizens.' Cfr. Article 37 thereof: '1. Anyone, being under the authority of the Polish State, shall enjoy the freedoms and rights ensured by the Constitution. 2. Exemptions from this principle with respect to foreigners shall be specified by statute.'

${ }^{104}$ See e.g. Canon 208ff of the Code of Canon Law (1983).

105 ibid Canon 1364.

${ }^{106}$ Cf De Sutter, 'Introduction' (n 85) 10.

${ }^{107}$ See Article 2 of the Labour Code: 'An employee is a person employed on the basis of an employment contract, appointment, election, nomination or a cooperative employment contract.' So-called 'trash contracts' are technically based not on the Labour Code, but on the Civil Code's contract of mandate (umowa zlecenia) or contract for the performance of a work (umowa o dzieto).

${ }^{108}$ Klara Kańska, 'Pojęcie konsumenta w kodeksie cywilnym na tle tendencji europejskich' [The Concept of a Consumer in the Civil Code Against European Tendencies] (2004) 13 (1) Kwartalnik Prawa Prywatnego 7.

109 ibid 10 .
} 
understood as emphasising the passive character of the individual in the economy, even referred to as homo oeconomicus passivus, a certain 'addition' to the business and market, ${ }^{110}$ or even the last link in the 'food chain' of commerce. ${ }^{111}$ The ideological interpellation of individuals in their capacity as consumers is conceptually opposed to their interpellation qua citizens. ${ }^{112}$ Interpellation qua consumers is referred to as 'commodification' of human rights and an off-shot of 'bread-and-circus politics', 113 and 'consumerism' is described as a commodification of human lives. ${ }^{114}$

In order to look well in the eyes of the big Other of neoliberalism, ${ }^{115}$ the individual interpellated as consumer must obey the injunction 'consume!'. As David Harvey points out:

“...capitalist consumer culture [...] perpetually plays with desires without ever conferring satisfactions beyond the limited identity of the shopping mall and the anxieties of status by way of good looks (in the case of women) or of material possessions. "I shop therefore I am" and possessive individualism together construct a world of pseudosatisfactions that is superficially exciting but hollow at its core." 116

In order to satisfy the symbolic mandate vested in them, consumers must indulge in the jouissance of possessive individualism, a jouissance in the strict sense of a 'pleasure beyond the pleasure principle', ${ }^{117}$ full of anxiety and giving only pseudo-satisfaction. Žižek makes an interesting attempt to place the neoliberal subjectivity of consumerism into the Lacanian triade of Real-Symbolic-Imaginary:

"At the level of consumption, this new spirit is that of so-called "cultural capitalism": we primarily buy commodities neither on account of their utility nor as status symbols; we buy them to get the experience provided by them, we consume them in order to render our lives pleasurable and meaningful. This triad cannot but evoke the Lacanian triad RSI: the Real of direct utility (good healthy food, the quality of a car, etc.), the Symbolic of the status (I buy a certain car to signal my status $[\ldots])$, the Imaginary of pleasurable and meaningful experience." $" 118$

\footnotetext{
${ }^{110}$ Cf Ewa Łętowska, Prawo umów konsumenckich [Consumer Contract Law] (2nd ed., C.H. Beck 2002) 40.

111 ibid 228.

112 See e.g. Martijn W. Hesselink, 'European Contract Law: a Matter of Consumer Protection, Citizenship, or Justice?' (2007) 15 (3) European Review of Private Law 323, 345 346; Mańko, 'Koncepcja' (n 41) 53.

113 Joseph H.H. Weiler, cited in Hesselink, 'European Contract Law' (n 111) 346.

114 Jane Hardy, Poland's New Capitalism (Pluto Press 2009) 214.

${ }^{115}$ I subscribe to Harvey's definition whereby 'Neoliberalism is in the first instance a theory of political economic practices that proposes that human well-being can best be advanced by liberating individual entrepreneurial freedoms and skills within an institutional framework characterized by strong private property rights, free markets, and free trade. The role of the state is to create and preserve an institutional framework appropriate to such practices. (...) State interventions in markets (once created) must be kept to a bare minimum (...).' David Harvey, A Brief History of Neoliberalism (first published 2005, OUP 2007) 2.

${ }^{116}$ Harvey, A Brief (n 115) 170.

${ }^{117}$ Fink, An Introduction (n 25) 226.

118 Žižek, First as Tragedy (n 74) 52.
} 
What Žižek points out is that the big Other's injunction 'consume!' goes beyond utility or status signification, but is performed in order to make the lives of consumers meaningful. Only by following the big Other's injunction can a human being make sense of himself in the gaze of the interpellating Subject.

\section{f. Confronting the fantasy with the Real}

The final stage of the ideological critique of a legal text with regard to the fantasies of selfhood conveyed in it can be the confrontation of the ideological fantasy, embodied in the interpellation, with the Real - something which escapes symbolisation, for instance, a fundamental social antagonism.

Let us take the example of the fundamental fantasy of labour law, namely that of equality of the parties to the labour contract. Leaving aside the narrow scope of labour law as such (with many employment relationships having the legal form of 'trash contracts' outside the Labour Code), let us confront the ideological fantasy with the Real it seeks to mask. On the side of the fantasy, the Polish Labour Code declares (in Art. $10 \S 1$ ) that 'everyone has the right to freely chosen employment', and in Art. 11 adds that 'the conclusion of an employment relationship and the determination of the conditions of work and pay [...] requires a unanimous declaration of will of the employer and employee', perhaps even suggesting some similarity between marriage and employment. However, the Real behind the fantasy of party autonomy cannot be overlooked. ${ }^{119}$

A similar critique can be waged against other fundamental fantasies of legal ideology, for instance the fantasy of power embodied in interpellation of individuals qua citizens. In the Symbolic register, all citizens jointly hold supreme power in the Republic (Art. 4 of the Polish Constitution). However, anyone having the faintest knowledge of 'actually existing' politics is fully aware that such a statement obviously rests upon a fiction. With a majoritarian electoral law which favours parties already present in parliament (also financially), and the role of financing in the forms of modern politics, it is obvious that an individual citizen or even a group of citizens has a negligible share in political power within the state. Casting a vote for this or another party, whilst capable of influencing certain issues, cannot change the fundamental socio-economic choices made in 1989. Individuals, hailed as 'citizens', are fully aware of these facts and therefore the majority opts for abstaining from the ideological ritual of voting. ${ }^{120}$ A similar critique can be waged against the ideology of judicial application of law, which overlooks the creative input of the judiciary, insisting on the fantasy of 'subsumption'.

Confronting the fantasy of (legal) ideology with the Real, the element that escapes symbolisation, allows the potential for critique to emerge, and allows subjects, if not to directly resist their interpellation, to at least relativise it and perceive it in a broader context.

\footnotetext{
${ }^{119}$ See e.g. Reykowski, 'Wolność' (n 63) 18.

${ }^{120}$ Hardy, Poland's (n 114) 200.
} 


\section{CONCLUSIONS: FROM REALITY TO DREAM?}

If, in Žižek's theoretical framework, fantasy is one side of reality, and reality is for those who cannot sustain the dream, one can enquire about the purpose of critique of (legal) ideology. Certainly, it is not aimed at formulating proposals de lege ferenda, that is for the amendment of laws or a change in the line of case-law. ${ }^{121}$ The fact that critique of ideology is directed at legal texts does not alter its main purpose: undermining the efficacy of the ideological grip held by the Symbolic order upon individuals by insisting on the classical Lacanian thesis that 'the big Other does not exist'. On a practical level, the critique of legal ideology performed by lawyers themselves can help to bring about a more reflexive approach to their participation in the principal practices of legal culture, namely legal scholarship, legal education and adjudication. ${ }^{122}$ The conciousness of law's ideological entanglements and its place within the more general scheme of the social construction of reality ${ }^{123}$ can help to raise lawyers' consciousness with regard to their role in society.

\section{References}

Althusser, L. 'Ideology and Ideological State Apparatus (Notes Towards and Investigation)' in idem, Lenin and Philosophy and Other Essays, transl. Ben Brewster (Aakar 2006).

Althusser, L. 'On Marx and Freud' (1991) 4 (1) Rethinking Marxism: A Journal of Economics, Culture \& Society.

Althusser, L. Ideologie i aparaty ideologiczne państwa (Studenckie Koło Filozofii Marksistowskiej UW 2006).

Berger, P \& Luckmann T. The Social Construction of Reality: A Treatise in the Sociology of Knowledge (first published 1966, Penguin 1991).

Burzyk, M. 'Psychoanaliza a polityka: stawka podmiotu' [Psychoanalysis and Politics: the Stake of the Subject] (2013) 35 Diametros.

Collins, H. Marxism and Law (first published 1982 OUP 1988).

Croce M \& Salvatore, A. The Legal Theory of Carl Schmitt (Routlege 2013).

De Sutter, L. 'Introduction' in idem (ed.) Althusser and Law (Routledge 2013).

Dębska, H. 'Iluzje prawniczego Rozumu: O społecznych warunkach praktyk (bez)refleksyjnych' [Illusions of the Legal Mind: On the Social Conditions of (Non-)Reflexive Practices] (2014) 42 Studia Prawno-Ekonomiczne 11.

Dębska, H. 'W okowach prawniczego sensus communis: O trudnościach uprawiania krytycznie zorientowanej socjologii prawa' [Shackled by the Legal Sensus Communis: On the Difficulties of Critically Oriented

\footnotetext{
${ }^{121}$ Mańko, 'Koncepcja' (n 41) 53.

${ }^{122}$ For this classification of practices of legal culture see e.g. Rafał Mańko, 'The Culture of Private Law in Central Europe After Enlargement: A Polish Perspective' (2005) 11.5 European Law Journal 527, 528; idem, 'The Unification of Private Law in Europe from the Perspective of Polish Legal Culture' (2007-2008) 11 Yearbook of Polish European Studies 109, 112-113 (with further references).

${ }^{123}$ Cf Berger and Luckmann, The Social Construction of Reality (n 1).
} 
Sociology of Law] (2014) 8 Archiwum Filozofii Prawa i Filozofii Społecznej.

Dębska, H. Władza - symbol - prawo. Społeczne tworzenie Trybunatu Konstytucyjnego [Power - Symbol - Law: The Social Construction of the Constitutional Court] (Wydawnictwo Sejmowe 2014)

Dębska, H. 'Law's Symbolic Power: Beyond the Marxist Conception of Ideology' (2015) 5 (1) Wrocław Review of Law, Administration and Economics.

Dolar, M. 'Beyond Interpellation' (1993) 6 (2) Qui Parle.

Evans, D. An Introductory Dictionary of Lacanian Psychoanalysis (Routledge 1996).

Fink, B. A Clinical Introduction to Lacanian Psychoanalysis: Theory and Technique (first published 1997, Harvard UP 1999).

García, G.I. \& Aguilar Sánchez, C. 'Psychoanalysis and politics: the theory of ideology in Slavoj Žižek’ (2008) 2 (3) International Journal of Žižek Studies.

Hardy, J. Poland's New Capitalism (Pluto Press 2009).

Hart, H L A. The Concept of Law (2nd edn, Clarendon Press 1994)

Harvey, D. A Brief History of Neoliberalism (first published 2005, OUP 2007).

Hesselink, MW. 'European Contract Law: a Matter of Consumer Protection, Citizenship, or Justice?' (2007) 15 (3) European Review of Private Law.

Kańska, K. 'Pojęcie konsumenta w kodeksie cywilnym na tle tendencji europejskich' [The Concept of a Consumer in the Civil Code Against European Tendencies] (2004) 13 (1) Kwartalnik Prawa Prywatnego.

Kelsen, H. Pure Theory of Law (tr Max Night (Lawbook Exchange 2005).

Kövecses, Z. Metaphor: A Practical Introduction (2nd ed., OUP 2010)

Kozak, A. Myślenie analityczne $w$ nauce prawa i praktyce prawniczej [Analytical Thinking in Legal Scholarship and Legal Practice] (Wydawnictwo Uniwersytetu Wrocławskiego 2010)

Krips, H. 'Interpellation, Populism, and Perversion: Althusser, Laclau and Lacan' (2007) 2 Filozofski Vestnik.

Lakoff G \& Johnson M. Metaphors We Live By (first published 1980, University of Chicago Press 2003).

Larsson, S. Metaphors and Norms: Understanding Copyright Law in a Digital Society (Lund University Press 2012).

Lenin, V I. The State and Revolution (first published 1918, Penguin 2009).

Łętowska, E. Prawo umów konsumenckich [Consumer Contract Law] (2nd edn, C.H. Beck 2002)

Llambías-Wolff, J. 'Law As The Expression Of Politics And The Result Of Its Own Dynamics' (2014) 3 (5) International Journal of Social Sciences.

Macherey P. \& Bundy, S. 'Judith Butler and the Althusserian theory of subjection', (2013) 1 (2) Décalages: An Althusser Studies Journal.

Mańko, R. 'Koncepcja interpelacji ideologicznej a krytyczny dyskurs o prawie' [The Notion of Ideological Interpellation and Critical Discourse on Law] (2014) 8 Archiwum Filozofii Prawa i Filozofii Społecznej.

Mańko, R. 'Quality of Legislation Following a Transition from Really Existing Socialism to Capitalism: A Case Study of General Clauses in Polish Private Law', in Jānis Rozenfelds (ed) The Quality of Legal Acts 
and its Importance in Contemporary Legal Space (University of Latvia Press 2012).

Mańko, R. 'The Culture of Private Law in Central Europe After Enlargement: A Polish Perspective' (2005) 11 (5) European Law Journal.

Mańko, R. 'The Unification of Private Law in Europe from the Perspective of Polish Legal Culture' (2007-2008) 11 Yearbook of Polish European Studies.

Marrani, D. 'Althusser in "Avatar", in Laurent de Sutter (ed) Althusser and Law (Routledge 2013).

Paździora M \& Stambulski, M. 'Co może dać nauce prawa polityczność? Przyczynek do przyszłych badań' [What Can Legal Scholarship Gain from the Notion of the Political? Notes Towards Further Investigations] (2014) 8 Archiwum Filozofii Prawa i Filozofii Społecznej.

Pfaller, R. 'Interpassivity and Misdemeanors: The Analysis of Ideology and the Žižekian Toolbox' (2007) 1 (1) International Journal of Žižek Studies.

Reykowski, J. 'Wolność gospodarcza jako ideologia' [Economic Freedom as Ideology] (2013) 210 Studia Socjologiczne.

Rüthers, B. Die unbegrentzte Auslegung: Zum Wandel der Privatrechtsordnung im Nationalsozialismus (7th edn, Mohr Siebeck 2012).

Schmitt, C. The Concept of the Political, transl. Georg Schwab (University of Chicago Press 2007).

Sheridan, A. 'Translators note' in Jacques Lacan, The Four Fundamental Concepts of Psychoanalysis, transl. Alan Sheridan (first published 1973, Hogarth Press 1978).

Sulikowski, A. 'Postmodernistyczne tropy w juryscentryzmie' [Postmodern Tropes in Juriscentrism], in Paweł Jabłoński, Przemysław Kaczmarek, Michał Paździora and Maciej Pichlak (eds) Perspektywy juryscentryzmu [The Perspectives of Juriscentrism] (Prawnicza i Ekonomiczna Biblioteka Cyfrowa 2011).

Sulikowski, A. Posthumanizm a prawoznawstwo [Posthumanism and Jurisprudence] (Wydawnictwo Uniwersytetu Opolskiego 2013).

Vespaziani, A. 'Towards a Hermeneutical Approach to Legal Metaphor', in Thomas Bustamante and Oche Onazi (eds) Human Rights, Language and Law (Franz Steiner/Nomos 2012).

Winter, S L. A Clearing in the Forest: Law, Life and Mind (University of Chicago Press 2001).

Wróbel, S. 'Efekt interpelacji' [The Effect of Interpellation] (2012) 56 Principia.

Zimmermann, R. The New German Law of Obligations: Historical and Comparative Perspectives (OUP 2005).

Žižek, S. First as Tragedy Then as Farce (Verso 2009).

Žižek, S. The Sublime Object of Ideology (first published 1989, Verso 2008). 